\title{
Uses of Isothiocyanate as Building Block in Syntheses of Triazole, Thiadiazole, Quinazoline, and Pyrimidine Systems of Agrochemical and Biological Activities
}

\author{
A.M.F. Fahmy, Hoda A. Abdel-Hamid and Nadia Y. Megally \\ Abdo* \\ Chemistry Department, Faculty of Science, Ain Shams University \\ and ${ }^{*}$ Chemistry Department, Faculty of Education, Alexandria \\ University, 21526 Alexandria, Egypt.
}

\begin{abstract}
DIFFERENT nitrogen heterocyclic compounds were synthesized in one pot reaction from 2-cyano-3-(4-hydroxy-3-methoxyphenyl) acryloyl isothiocyanate (2) as building block. The structures of the newly synthesized compounds were confirmed on the basis of their elemental and spectral analyses. The effect of the synthesized compounds on the growth of Hordeum coleoptile section using straight growth test for auxins and inhibitors has been studied. Moreover, some of the synthesized compounds were screened for their in vitro antibacterial activity against Bacillus cereus (Gram-positive bacteria), Salmonella (Gram negative bacteria) and antifungal activity against Aspergillus niger.
\end{abstract}

Keywords: Acryloyl isothiocyannate, Agro chemical activity and Antimicrobial activity .

Among the wide variety of heterocycles, pyrimidinone/thione and their derivatives have occupied an important position in natural and synthetic organic chemistry due to their wide range of biological activities, such as antioxidant, anti-inflammatory, anthelmintic, antimicrobial ${ }^{(1-3)}$. Pyrimidines have shown excellent broad spectrum herbicidal activity in transplanted paddy rice ${ }^{(4)}$, agro chemical fungicides ${ }^{(5,6)}$ and exhibit remarkable activity as rubella virus inhibitors ${ }^{(7,8)}$.

In addition, compounds incorporating substituted 1,2,4-triazole and 1,3,4thiadiazole rings have been attracting widespread attention due to their diverse pharmacological properties such as antimicrobial, anti-inflammatory, analgesic and antitumor activities ${ }^{(9-12)}$.

Moreover, Quinazolinones have a diverse range of biological activities such as antibacterial, antifungal, analgesic, anti-inflammatory, cytotoxicity and diuretic $^{(13-16)}$.

\footnotetext{
*To whom correspondence should be addressed. E-mail: nadiamegally@yahoo.com
} 
In the process of searching for new active compounds, a number of heterocyclic systems carrying substituent (4-hydroxy-3-methoxyphenyl) as well as a cyano group and a thione have been synthesized. Therefore, our synthetic strategy is to synthesize heterocyclic systems using 2-cyano-3-(4-hydroxy-3methoxyphenyl)acryloyl isothiocyanate (2) as building block. The synthesized compounds were screened for their antibacterial, antifungal activities and their effect on the growth of Hordeum coleoptile section.

\section{Chemistry}

\section{Results and Discussion}

Biologically active heterocyclic compounds containing thione groups were synthesized in one pot reaction starting from 2-cyano-3-(4-hydroxy-3methoxyphenyl)acryloyl isothiocyanate (2). Unstable acryloyl isothiocyanate derivative (2) was prepared in situe in the following reactions from the reaction of acid chloride (1) with ammonium thiocyanate in dry acetone. Triazole derivative (3) was prepared from the reaction of phenyl hydrazine with isothiocyanate (2) the reaction proceeds via addition of phenyl hydrazine to the isothiocyanate followed by exo-trig cyclization (Scheme 1). The structure of compound 3 was confirmed on the basis of its analytical and spectral data. The IR spectrum showed the absence of $\gamma \mathrm{C}=\mathrm{O}$ band beside the presence of signals corresponding to $\gamma \mathrm{NH}$ $\left(3390 \mathrm{~cm}^{-1}\right), \gamma \mathrm{CN}\left(2280 \mathrm{~cm}^{-1}\right)$ and $\gamma \mathrm{C}=\mathrm{S}\left(1388 \mathrm{~cm}^{-1}\right)$, respectively which supports the formation of 3 . Moreover, the ${ }^{1} \mathrm{H}$ NMR spectrum revealed the presence of three singlets at $\delta 3.83,7.98,10.2 \mathrm{ppm}$ corresponding to the $\mathrm{OCH}_{3}$, $\mathrm{CH}=\mathrm{C}-$ and $\mathrm{OH}$ protons $\left(\mathrm{D}_{2} \mathrm{O}\right.$ exchangeable $)$, respectively beside the multiplet at $\delta 6.93-7.62 \mathrm{ppm}$ for 8 aromatic protons and one $\mathrm{NH}$ proved the formation of triazole ring.

Addition of benzoyl hydrazine to isothiocyanate (2) afforded the benzoylhydrazinocarbonothioyl derivative (4) .Reaction of compound 4 with poly phosphoric acid in acetic acid involves the attack of the nucleophilic sulphur on the carbonyl group of the benzoyl moiety, followed by elimination of water molecule producing 1,3,4-thiadiazole derivative 5 (Scheme 1). The absence of thiocarbonyl $\gamma \mathrm{C}=\mathrm{S}$ and $\gamma \mathrm{C}=\mathrm{O}$ of the benzoyl moiety in the IR spectrum, beside the presence of only one $\mathrm{NH}$ in the ${ }^{1} \mathrm{H}$ NMR spectrum confirmed the formation of thiadiazole ring.

Moreover, when the isothiocyanate (2) reacts with anthranilic acid, acryloyl(thioureido)benzoic acid derivative (6) was obtained. Cyclization of 6 using acetic anhydride gave the 1,2-dihydroquinazoline derivative (7) (Scheme 1). The structure of 7 was confirmed on the basis of its analytical and spectral data (see the experimental section).

Egypt. J. Chem. 58, No. 6 (2015) 


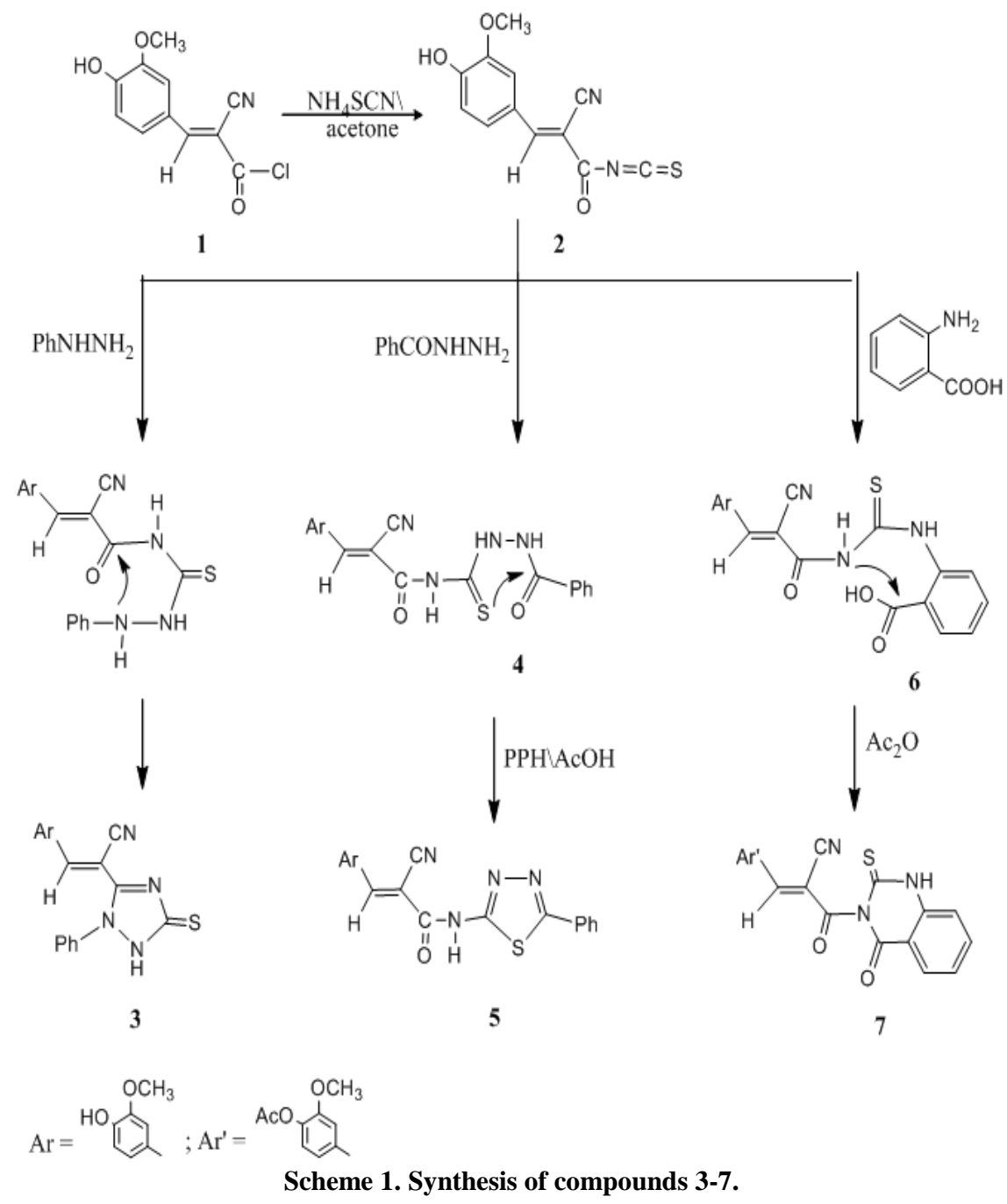

Reaction of isothiocyanate (2) with aromatic amines namely; aniline, ptoluidine and p-anisidine, gives different products depending upon the amine. In case of aniline, the product was hexahydropyrimidine derivative (8a). On the other hand, the reaction of 2 with p-toluidine afforded the thiourea derivative (9b). While, when the isothiocyanate 2 was treated with p-anisidine, the product was an equilibrium mixture of the thiourea derivative $(9 c)$ and the pyrimidine derivative (8b) (Scheme 2). 

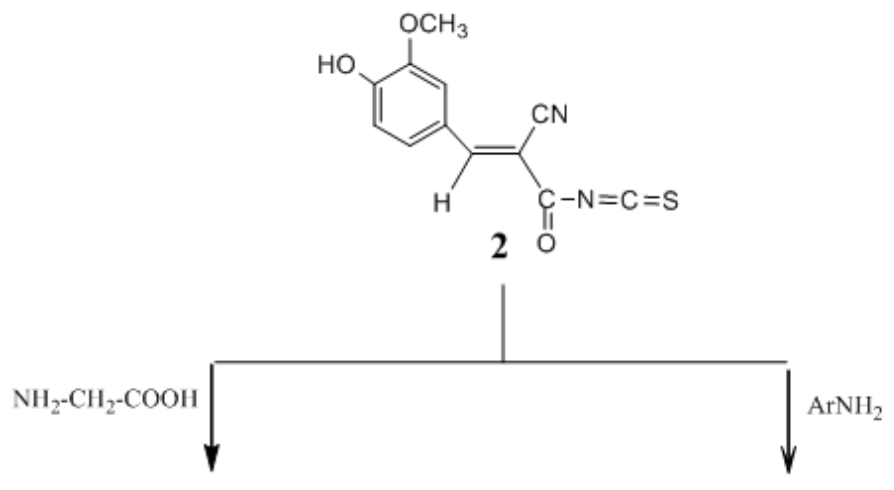<smiles>COc1cc(/C=C2\C(=O)CNC(=S)NC2=O)ccc1O</smiles>

10<smiles>COc1cc(/C=C2\C(=N)N(CC(=O)O)C(=S)NC2=O)ccc1O</smiles>

11

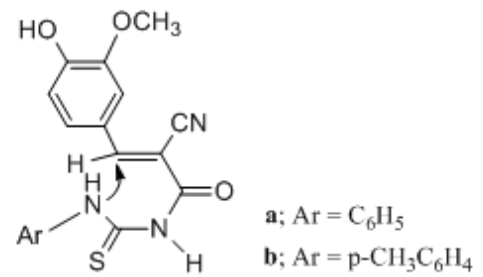

9a-c c; $\mathrm{Ar}=\mathrm{p}-\mathrm{OCH}_{3} \mathrm{C}_{6} \mathrm{H}_{4}$<smiles>C=C</smiles><smiles>COc1cc([C@@]2(C)[C@H](C#N)C(=O)NC(=S)N2[14CH3])ccc1O</smiles>

$\mathbf{a} ; \mathrm{Ar}=\mathrm{C}_{6} \mathrm{H}_{5}$

8a,b $\quad$ b; $\mathrm{Ar}=\mathrm{p}-\mathrm{OCH}_{3} \mathrm{C}_{6} \mathrm{H}_{4}$

Scheme 2. Synthesis of compounds 8a, 9b, 8b $\rightleftharpoons 9 \mathrm{c}$ and 11 .

The reaction proceeds through the addition of amines to the isothiocyanate (2) producing the thiourea derivative intermediate (9a-c) which cyclize (in case of $8 \mathrm{a})$ via Aza Micahel ${ }^{(17)}$ addition of the $\mathrm{NH}$ on the olifinic bond $(\mathrm{HC}=\mathrm{C}-)$ of the acryloyl moiety forming the pyrimidine derivative (8a). The structure of compounds $8 \mathrm{a}, \mathrm{b}$ and $9 \mathrm{a}-\mathrm{c}$ was confirmed on the basis of their analytical and spectral data. Therefore, ${ }^{1} \mathrm{H}$ NMR spectrum of compound $8 \mathrm{a}$ showed the presence of two singlets at $\delta 12.1$ and $9.2 \mathrm{ppm}\left(\mathrm{D}_{2} \mathrm{O}\right.$ exchangeable) due to the presence of $\mathrm{OH}$ and $\mathrm{NH}$ groups, beside another singlet at $\delta 3.7 \mathrm{ppm}$ for $\left(\mathrm{OCH}_{3}\right)$.

Egypt. J. Chem. 58, No. 6 (2015) 
The presence of three doublets at 5.2, 5.4 and $5.7 \mathrm{ppm}$ due to coupling between $\mathrm{H}_{\mathrm{a}}$ and $\mathrm{H}_{\mathrm{b}}$, beside the absence of signal corresponding to the $\mathrm{HC}=\mathrm{C}-$ (olefinic proton) prove the formation of hexahydropyrimidine ring. While, in case of p-anisidine, the presence of signals at $9.2(\mathrm{NH}), 8.2(\mathrm{HC}=\mathrm{C}-)$ as well as the three doublets at 5.62, 5.35 and $5.14 \mathrm{ppm}$ all of them integrating for two protons proved contribution of the structures $8 \mathrm{~b}$ and $9 \mathrm{c}$ in equilibrium ${ }^{(18-20)}$.

On the other hand, reaction of isothiocyanate 2 with glycine gives hexahydropyrimidine derivative 11 (Scheme 2). The reaction takes place via the intermediate formation of the acryloyl((thioureido)acetic acid derivative 10 which undergoes exo-dig cyclization via nucleophilic addition of $\mathrm{NH}$ on the cyano group of the acryloyl moiety. The IR spectrum of 11 showed the absence of $\gamma \mathrm{CN}$ band beside the presence of broad $\gamma \mathrm{OH}$ at $3600-3100 \mathrm{~cm}^{-1}$ and two bands at $\gamma 1810, \gamma 1770 \mathrm{~cm}^{-1}$ for 2CO of cyclic amide and aliphatic acid, respectively which supports the formation of final product. Moreover, the presence of singlets at $\delta 3.98 \mathrm{ppm}$ for the imino group $\left(-\mathrm{C}=\mathrm{NH}, \mathrm{D}_{2} \mathrm{O}\right.$ exchangeable), $4.67 \mathrm{ppm}\left(\mathrm{CH}_{2}\right), 7.94 \mathrm{ppm}(\mathrm{HC}=\mathrm{C}-)$ in addition to two singlets at $\delta 10.54,11.33 \mathrm{ppm}$ for two hydroxyl groups $\left(\mathrm{D}_{2} \mathrm{O}\right.$ exchangeable $)$ in the ${ }^{1} \mathrm{H}$ NMR spectrum proved the formation of imino pyrimidine structure.

\section{Biological activity}

Effect on the growth of Hordeum coleoptile sections

In this work, a number of heterocyclic systems carrying, in addition to the ring, other substituent (4-hydroxy-3-methoxy phenyl) as well as a cyano group and a thione. These rings are thought to have biological activity and this is why in this section, we have selected compounds $(3,8 \mathrm{a}, 9 \mathrm{~b}, 8 \mathrm{~b} \rightleftharpoons 9 \mathrm{c})$ and we have studied their effect on the growth test for auxins and inhibitors ${ }^{21)}$. The obtained results are given in Table 1 and represented graphically in Fig. 1 and 2. The graph gives the variation of the length of coleoptile sections as percentage of control (in water) against concentration in ppm.

In all studied compounds, it was found that the relative high concentrations $\left(10^{3}\right.$ and $\left.10^{2}\right)$ inhibited the growth of Hordeum coleoptile sections, while the relative lower concentrations of all compounds studied, except the thiourea derivative (9b) stimulated this growth as being compared with the control (water). The optimum concentrations for growth stimulation was found to be $10^{-2}$ for triazoline thione (3) and $10^{-3}$ for pyrimidine thione $(8 \mathrm{a}, 8 \mathrm{~b} \rightleftharpoons 9 \mathrm{c})$. 
TABLE 1. Growth of Hordeum coleoptile sections as affected by different concentration.

\begin{tabular}{|c|c|c|c|c|}
\hline \multirow{2}{*}{$\begin{array}{c}\text { Concentration } \\
(\mathbf{p p m})\end{array}$} & \multicolumn{5}{|c|}{ Mean length of coleoptile sections as \% of control } \\
\cline { 2 - 5 } & $\begin{array}{c}\text { Compound } \\
\mathbf{( 3 )}\end{array}$ & $\begin{array}{c}\text { Compound } \\
\mathbf{8 a}\end{array}$ & $\begin{array}{c}\text { Compound } \\
\mathbf{9 b}\end{array}$ & $\begin{array}{c}\text { Compound } \\
\mathbf{8 b} \rightleftharpoons \mathbf{9 c}\end{array}$ \\
\hline 0.0 (control) & 100 & 100 & 100 & 100 \\
\hline $10^{3}$ & 85 & 86 & 81 & 83 \\
\hline $10^{2}$ & 93 & 93 & 90 & 93 \\
\hline $10^{1}$ & 100 & 100 & 97 & 97 \\
\hline $10^{0}$ & 103 & 102 & 96 & 100 \\
\hline $10^{-1}$ & 101 & 103 & 98 & 103 \\
\hline $10^{-2}$ & 112 & 105 & 103 & 105 \\
\hline $10^{-3}$ & 106 & 106 & 100 & 107 \\
\hline $10^{-4}$ & 106 & 103 & 100 & 107 \\
\hline $10^{-5}$ & 105 & 102 & 100 & 100 \\
\hline $10^{-6}$ & 105 & 101 & 100 & 99.3 \\
\hline
\end{tabular}

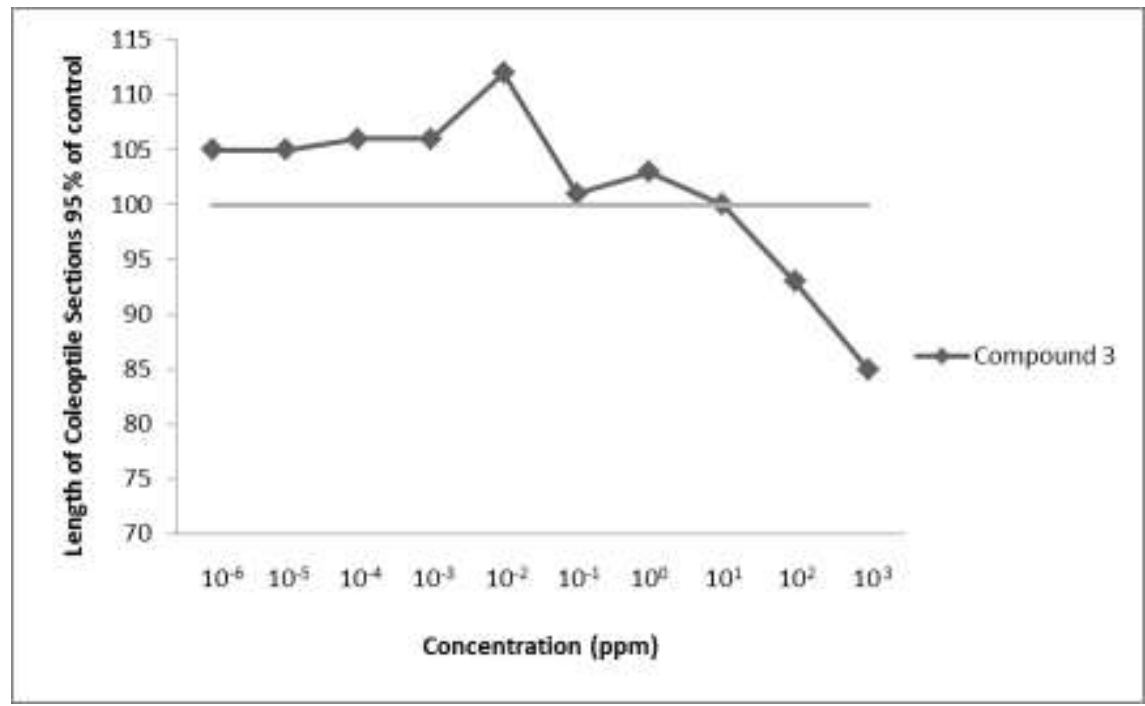

Fig. 1. Effect of compound 3 on the growth of Hordeum coleoptile sections .

The above results indicate that the compounds under investigation are biologically active and may be of hormonal nature.

In vitro antimicrobial activity

The synthesized compounds 3, 7, 8a, 9b and 8b 9c were tested for their antibacterial activity against two test organisms, Bacillus cereus (gram positive bacteria), Salmonela (gram negative bacteria) using the agar well-diffusion method $^{(22)}$ for studying the potential activities of these compounds using rifampicin $(5 \mu \mathrm{g} / \mathrm{disc})$ and ampicillin $(10 \mu \mathrm{g} / \mathrm{disc})$ as standard drugs.

Egypt. J. Chem. 58, No. 6 (2015) 


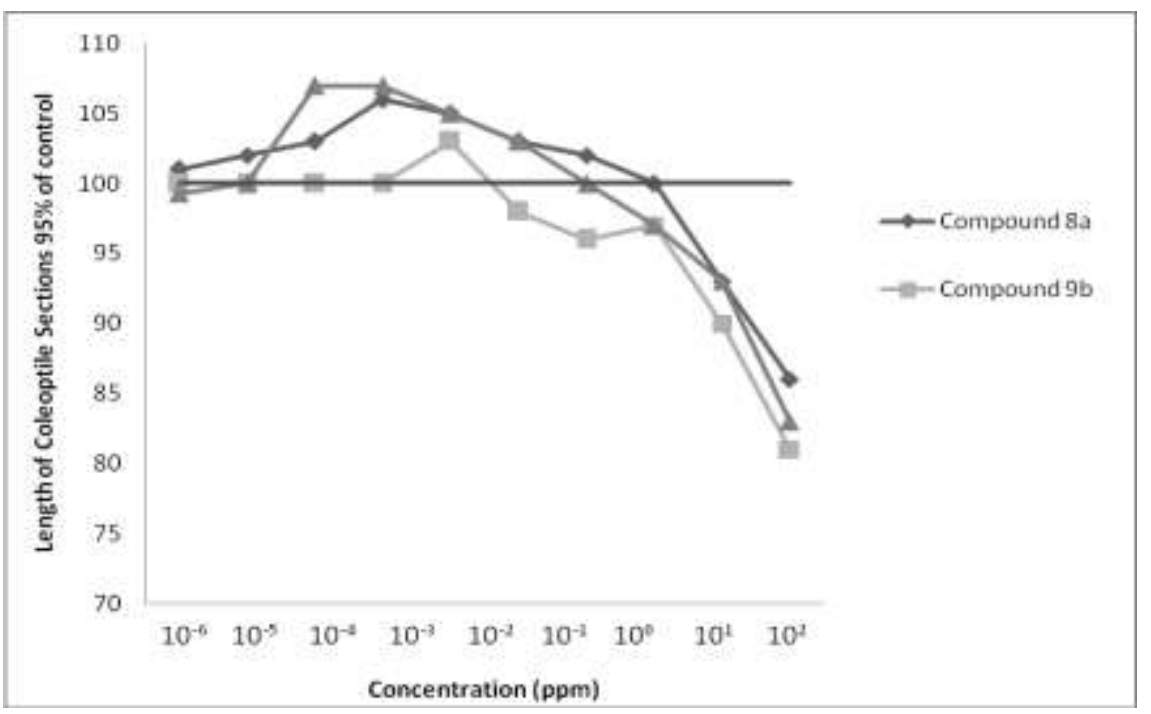

Fig. 2. Effect of compounds $8 \mathrm{a}, 9 \mathrm{~b}$ and $8 \mathrm{~b} \rightleftharpoons 9 \mathrm{c}$ on the growth of Hordeum coleoptile sections.

The antifungal activity of the synthesized compounds was tested against Aspergillus niger by a filter paper disc technique ${ }^{(23)}$. It was found that all tested compounds showed no significant effect against Salmonela and Aspergillus niger, whereas compounds 7,9b and 8b 9c were active against Bacillus cereus. Minimum inhibitory concentration (MIC) values for the active compounds that showed inhibition zones $>10 \mathrm{~mm}$ were determined by means of the agar welldiffusion method in DMSO. The trend of activity was observed as follows: pyrimidine tautomer $8 \mathrm{~b} 9 \mathrm{c}>$ Thio urea $9 \mathrm{~b}>$ quinazoline derivative 7 . The activity results of the synthesized compounds against Bacillus cereus shown in Table 2 as zone of inhibition (in $\mathrm{mm}$ ) and minimum inhibitory concentration, $\mathrm{MIC}(\mathrm{mg} / \mathrm{ml})$.

\section{Conclusions}

In this study, different nitrogen heterocyclic compounds were prepared in one pot reaction from 2-cyano-3-(4-hydroxy-3-methoxyphenyl)acryloyl isothiocyanate (2) through its reaction with different reagents. The effect of the synthesized compounds on the growth of Hordeum coleoptile section using straight growth test for auxins and inhibitors has been studied. The screening result showed that the relative high concentrations $\left(10^{3}\right.$ and $\left.10^{2}\right)$ inhibited the growth of Hordeum coleoptile sections. Moreover, the synthesized compounds 3, 7, 8a, 9b and 8b 9c were tested for their antibacterial activity against two test organisms, Bacillus cereus, Salmonela and antifungal activity against Aspergillus niger. It was found that, compounds 7,9b and 8b 9c were active against Bacillus cereus. 
TABLE 2. Determination of zone of inhibition and minimum inhibitory concentrations (MIC).

\begin{tabular}{|c|c|c|}
\hline \multirow{2}{*}{ Compound No. } & $\begin{array}{c}\text { Zone of Inhibition } \\
(\mathbf{m m})\end{array}$ & $\begin{array}{c}\text { Minimum Inhibitory } \\
\text { Concentration } \\
(\mathbf{M I C}) \mathbf{m g} / \mathbf{m l}\end{array}$ \\
\cline { 2 - 3 } & Bacillus cereus & Bacillus cereus \\
\hline 3 & - & - \\
\hline 7 & 18 & 0.063 \\
\hline $8 \mathrm{a}$ & - & 0.063 \\
\hline $9 \mathrm{~b}$ & 19 & 0.05 \\
\hline $8 \mathrm{~b} 9 \mathrm{c}$ & 22 & - \\
\hline Rifampicin & 32 & - \\
\hline Ampicillin 3 & 30 & - \\
\hline DMSO & - & \\
\hline
\end{tabular}

(-): No activity.

\section{Experimental}

All melting points were determined on a Stuart apparatus and the values given are uncorrected. IR spectra were determined on a Unicam SP 2000 using $\mathrm{KBr}$, Wafer techniques and Mattson- 1000 FTIR spectrometer (Faculty of Science, Ain Shams University, Egypt). ${ }^{1} \mathrm{H}-\mathrm{NMR}$ and ${ }^{13} \mathrm{C}-\mathrm{NMR}$ spectra were recorded on a Varian Gemini 200, at $200 \mathrm{MHz}$ and Varian EM-390 at $90 \mathrm{MHz}$ spectrometer using TMS as the internal standard. Chemical shift values were recorded in ppm on $\delta$ scale. Mass spectra were recorded on a Shimadzu single focusing mass spectrometer at a beam energy $70 \mathrm{ev}$, where samples were introduced via a direct inlet system to the source; operating temperature at $250{ }^{\circ} \mathrm{C}$ (Microanalysis Center, Cairo University, Egypt). Elemental analyses were carried out by perkin-Elmer 2400.CHN, elemental analyser (Microanalysis Center, Cairo University, Egypt). The progress of the reactions was monitored using thin layer chromatography (TLC) sheets precoated with UV fluorescent silica gel Merck 60F 254 and were visualized using UV lamp

Synthesis of 2-cyano-3-(4-hydroxy-3-methoxyphenyl)acryloyl chloride (1)

A mixture of 2-cyano-3-(4-hydroxy-3-methoxyphenyl)acrylic acid.(2.19 g, $0.01 \mathrm{~mol}$ ) (prepared from the saponification of ethyl 2-cyano-3-(4-hydroxy-3methoxyphenyl(acrylate $\left.{ }^{(24)}\right)$ and thionyl chloride $(50 \mathrm{ml})$ was heated under reflux on a boiling water bath for $2 \mathrm{hr}$. The excess thionyl chloride was distilled off, leaving a yellow product of 2-cyano-3-(4-hydroxy-3-methoxyphenyl)acryloyl chloride (1) Yield: 95\%; m.p.: $125-127{ }^{\circ} \mathrm{C}$; IR $\left(\mathrm{KBr}, \mathrm{cm}^{-1}\right): 3400(\mathrm{OH}), 3048$ (CH aromatic), $2220(\mathrm{CN}), 1750(\mathrm{C}=\mathrm{O})$.

Synthesis of 2-cyano-3-(4-hydroxy-3-methoxyphenyl)acryloyl isothiocyanate (2)

When ammonium thiocyanate $(0.76 \mathrm{~g}, 0.01 \mathrm{~mol})$ was added to a solution of 2-cyano-3-(4-hydroxy-3-methoxyphenyl)acryloyl chloride (1) (2.37 g, $0.01 \mathrm{~mol})$

Egypt. J. Chem. 58, No. 6 (2015) 
in dry acetone with stirring for $30 \mathrm{~min}$, the reaction mixture was filtered off to get rid of ammonium chloride. The acetone solution contains 2-cyano-3-(4hydroxy-3-methoxyphenyl)acryloyl isothiocyanate (2) was used for the following reactions.

Synthesis of 3-(4-hydroxy-3-methoxyphenyl)-2-(2-phenyl-5-thioxo-2,5-dihydro-1H1,2,4-triazol-3-yl)acrylonitrile (3)

Phenyl hydrazine $(1.08 \mathrm{~g}, 0.01 \mathrm{~mol})$ was added to a solution of 2-cyano-3-(4hydroxy-3-methoxyphenyl)acryloyl isothiocyanate (2) $(0.01 \mathrm{~mol})$ prepared in situ in dry acetone. The reaction mixture was heated under reflux on a boiling water bath for $1 \mathrm{hr}$ and the yellow product was precipitated, filtered off and crystallized from acetic acid.

Yield: $80 \%$; m.p.: $263-265^{\circ} \mathrm{C}$; IR (KBr, cm $\left.{ }^{-1}\right): 3390(\mathrm{NH}), 2280(\mathrm{CN}), 1388$ $(\mathrm{C}=\mathrm{S}) ;{ }^{1} \mathrm{H}$ NMR $\left(\mathrm{DMSO}-d_{6}\right): \delta 3.83\left(\mathrm{~s}, 3 \mathrm{H}, \mathrm{OCH}_{3}\right), 6.93-7.62(\mathrm{~m}, 9 \mathrm{H}, 8 \mathrm{Ar}-\mathrm{H}$ and $1 \mathrm{NH}), 7.98(\mathrm{~s}, 1 \mathrm{H}, \underline{\mathrm{HC}}=\mathrm{C}-), 10.22\left(\mathrm{~s}, 1 \mathrm{H}, \mathrm{OH}, \mathrm{D}_{2} \mathrm{O}\right.$ exchangeable); MS: $m / z(\%) 350\left(\mathrm{M}^{+}, 86.6\right)$. Anal. Calcd. for $\mathrm{C}_{18} \mathrm{H}_{14} \mathrm{~N}_{4} \mathrm{O}_{2} \mathrm{~S}: \mathrm{C}, 61.7 ; \mathrm{H}, 4.03 ; \mathrm{N}$, 15.99; S, 9.15. Found: C, 61.23; H, 3.86; N, 15.74; S, 8.95.

Synthesis of N-(2-benzoylhydrazinecarbonothioyl)-2-cyano-3-(4-hydroxy-3methoxyphenyl)acrylamide (4)

Benzoyl hydrazine (1.36 g, $0.01 \mathrm{~mol})$ was added to a solution of 2-cyano-3(4-hydroxy-3-methoxyphenyl)acryloyl isothiocyanate (2) (0.01 mol) prepared in situ in dry acetone. The reaction mixture was heated under reflux for $30 \mathrm{~min}$. On evaporation of the excess acetone, a yellow product was precipitated, crystallized from toluenelethanol mixture.

Yield: 83\%; m.p.: $198-199{ }^{\circ} \mathrm{C}$; IR $\left(\mathrm{KBr}, \mathrm{cm}^{-1}\right): 3400-3260(3 \mathrm{NH}), 2212$ $(\mathrm{CN}), 1680,1660(2 \mathrm{C}=\mathrm{O}), 1310(\mathrm{C}=\mathrm{S}) ;{ }^{1} \mathrm{H}$ NMR $\left(\mathrm{DMSO}-d_{6}\right): \delta 3.81(\mathrm{~s}, 3 \mathrm{H}$, $\left.\mathrm{OCH}_{3}\right), 7.01-7.62(\mathrm{~m}, 9 \mathrm{H}, 8 \mathrm{Ar}-\mathrm{H}$ and $1 \mathrm{NH}), 7.96(\mathrm{~s}, 1 \mathrm{H}, \underline{\mathrm{HC}}=\mathrm{C}-), 8.56(\mathrm{~s}, 2 \mathrm{H}$, $\mathrm{NH}, \mathrm{D}_{2} \mathrm{O}$ exchangeable), $10.54\left(\mathrm{~s}, 1 \mathrm{H}, \mathrm{OH}, \mathrm{D}_{2} \mathrm{O}\right.$ exchangeable); $\mathrm{MS}: \mathrm{m} / \mathrm{z}(\%)$ $396\left(\mathrm{M}^{+}\right.$, 55.7). Anal. Calcd. for $\mathrm{C}_{19} \mathrm{H}_{16} \mathrm{~N}_{4} \mathrm{O}_{4} \mathrm{~S}: \mathrm{C}, 57.57 ; \mathrm{H}, 4.07 ; \mathrm{N}, 14.13 ; \mathrm{S}$, 8.09. Found: C, 57.83; H, 4.06; N, 13.8; S, 7.89.

Synthesis of 2-cyano-3-(4-hydroxy-3-methoxyphenyl)-N-(5-phenyl-1,3,4-thiadiazol2-yl)acrylamide (5)

When a solution of compound $4(3.96 \mathrm{~g}, 0.01 \mathrm{~mol})$ was heated under reflux with a mixture of polyphophoric acid $(0.01 \mathrm{~mol})$ in acetic acid $(5 \mathrm{ml})$ for $2 \mathrm{hr}$, a yellow product was precipitated, filtered off, crystallized from acetic acid.

Yield: 75\%; m.p.: 233-235 ${ }^{\circ} \mathrm{C}$; IR (KBr, $\left.\mathrm{cm}^{-1}\right): 3403(\mathrm{NH}), 2202(\mathrm{CN}), 1670$ $(\mathrm{C}=\mathrm{O}) ;{ }^{1} \mathrm{H}$ NMR $\left(\mathrm{DMSO}-d_{6}\right): \delta 3.79\left(\mathrm{~s}, 3 \mathrm{H}, \mathrm{OCH}_{3}\right), 7.12-7.73(\mathrm{~m}, 8 \mathrm{H}, \mathrm{Ar}-\mathrm{H})$, $7.94(\mathrm{~s}, 1 \mathrm{H}, \underline{\mathrm{HC}}=\mathrm{C}-), 8.56\left(\mathrm{~s}, 1 \mathrm{H}, \mathrm{NH}, \mathrm{D}_{2} \mathrm{O}\right.$ exchangeable $) 10.54(\mathrm{~s}, 1 \mathrm{H}, \mathrm{OH}$, $\mathrm{D}_{2} \mathrm{O}$ exchangeable); MS: $m / z(\%) 378\left(\mathrm{M}^{+}, 70.6\right)$. Anal. Calcd. for $\mathrm{C}_{19} \mathrm{H}_{14} \mathrm{~N}_{4} \mathrm{O}_{3} \mathrm{~S}$ : C, 60.31; H, 3.73; N, 14.81; S, 8.47. Found: C, 60.53; H, 3.96; N, 14.65; S, 8.23. 
Synthesis of 2-(3-(2-cyano-3-(4-hydroxy-3-methoxyphenyl)acryloyl) thioureido) benzoic acid (6)

Anthranilic acid $(1.37 \mathrm{~g}, 0.01 \mathrm{~mol})$ was added to a solution of 2-cyano-3-(4hydroxy-3-methoxyphenyl)acryloyl isothiocyanate (2) (0.01 mol) prepared in situ in dry acetone. The reaction mixture was heated under reflux on a boiling water bath for $30 \mathrm{~min}$. On evaporation of the excess acetone, a yellow product was precipitated and crystallized from acetic acid.

Yield: 75\%; m.p.: $182-184{ }^{\circ} \mathrm{C}$; IR $\left(\mathrm{KBr}, \mathrm{cm}^{-1}\right): 3350-3260$ (2NH), 2220 $(\mathrm{CN}), 1730,1690(2 \mathrm{C}=\mathrm{O}), 1340(\mathrm{C}=\mathrm{S}) ;{ }^{1} \mathrm{H}$ NMR (DMSO-d $): \delta 3.78(\mathrm{~s}, 3 \mathrm{H}$, $\left.\mathrm{OCH}_{3}\right), 6.98-7.59(\mathrm{~m}, 7 \mathrm{H}, \mathrm{Ar}-\mathrm{H}), 7.97(\mathrm{~s}, 1 \mathrm{H}, \underline{\mathrm{HC}}=\mathrm{C}-), 8.61\left(\mathrm{~s}, 2 \mathrm{H}, 2 \mathrm{NH}, \mathrm{D}_{2} \mathrm{O}\right.$ exchangeable), $10.54\left(\mathrm{~s}, 1 \mathrm{H}, \mathrm{OH}, \mathrm{D}_{2} \mathrm{O}\right.$ exchangeable), $11.33\left(\mathrm{~s}, 1 \mathrm{H}, \mathrm{OH}, \mathrm{D}_{2} \mathrm{O}\right.$ exchangeable); MS: $m / z$ (\%) $397\left(\mathrm{M}^{+}, 15.4\right)$. Anal. Calcd. for $\mathrm{C}_{19} \mathrm{H}_{15} \mathrm{~N}_{3} \mathrm{O}_{5} \mathrm{~S}: \mathrm{C}$, 57.42; H, 3.80; N, 10.57; S, 8.07. Found: C, 57.13; H, 3.54; N, 10.34; S, 8.21.

Synthesis of 4-(2-cyano-3-oxo-3-(4-oxo-2-thioxo-1,2-dihydroquinazolin-3(4H)yl)prop-1-en-1-yl)-2-methoxyphenyl acetate (7)

A solution of compound 6 (3.97 g, $0.01 \mathrm{~mol})$ was heated under reflux with $10 \mathrm{ml}$ acetic anhydride for $1.5 \mathrm{hr}$. The white product was precipitated, filtered off, crystallized from Toluene.

Yield: 60\%; m.p.: 210-211 ${ }^{\circ} \mathrm{C}$; IR (KBr, cm $\left.{ }^{-1}\right): 3400(\mathrm{NH}), 2220(\mathrm{CN}), 1770$, 1670, $1650(3 \mathrm{C}=\mathrm{O}), 1370(\mathrm{C}=\mathrm{S}) ;{ }^{1} \mathrm{H}$ NMR $\left(\mathrm{DMSO}-d_{6}\right): \delta 2.39\left(\mathrm{~s}, 3 \mathrm{H}, \mathrm{CH}_{3}\right), 3.79$ $\left(\mathrm{s}, 3 \mathrm{H}, \mathrm{OCH}_{3}\right), 6.98-7.59(\mathrm{~m}, 7 \mathrm{H}, \mathrm{Ar}-\mathrm{H}), 7.91(\mathrm{~s}, 1 \mathrm{H}, \underline{\mathrm{HC}}=\mathrm{C}-), 8.61(\mathrm{~s}, 1 \mathrm{H}, \mathrm{NH}$, $\mathrm{D}_{2} \mathrm{O}$ exchangeable); MS: $m / z(\%) 421\left(\mathrm{M}^{+}, 5.7\right)$. Anal. Calcd. for $\mathrm{C}_{21} \mathrm{H}_{15} \mathrm{~N}_{3} \mathrm{O}_{5} \mathrm{~S}$ : C, 59.85; H, 3.59; N, 9.97; S, 7.61. Found: C, 59.63; H, 3.54; N, 9.62; S, 7.45.

General procedure for the synthesis of $8 a, b$ and $9 a-c$

Aromatic amines namely: aniline $(0.93 \mathrm{~g}, 0.01 \mathrm{~mol}), \mathrm{p}$-toluidine $(1.07 \mathrm{~g}, 0.01$ mol) and p-anisidine $(1.23 \mathrm{~g}, 0.01 \mathrm{~mol})$ were added to a solution of 2-cyano-3(4-hydroxy-3-methoxyphenyl)acryloyl isothiocyanate (2) (0.01 mol) prepared in situ in dry acetone. The reaction mixture was heated under reflux on a boiling water bath for $30 \mathrm{~min}$ and left to cool. On evaporation of the excess acetone, the yellow product was precipitated, filtered off and crystallized from toluene.

Synthesis of 6-(4-hydroxy-3-methoxyphenyl)-4-oxo-1-phenyl-2 thioxohexahydropyrimidine 5-carbonitrile $(8 a)$

Yield: $75 \%$; m.p.: $181-182^{\circ} \mathrm{C}$; IR (KBr, cm $\left.{ }^{-1}\right): 3369(\mathrm{NH}), 2220(\mathrm{CN}), 1680$ $(\mathrm{C}=\mathrm{O}), 1370(\mathrm{C}=\mathrm{S}) ;{ }^{1} \mathrm{H}$ NMR (DMSO-d $): \delta 3.79\left(\mathrm{~s}, 3 \mathrm{H}, \mathrm{OCH}_{3}\right), 5.21,5.43,5.72$ (3d, 2H, pyrimidine $\mathrm{H}_{\mathrm{a}}$ and $\mathrm{H}_{\mathrm{b}}$ ) , 6.98-7.59 (m, 8H, Ar-H), 9.21 (s, 1H, NH, $\mathrm{D}_{2} \mathrm{O}$ exchangeable) $12.14\left(\mathrm{~s}, 1 \mathrm{H}, \mathrm{OH}, \mathrm{D}_{2} \mathrm{O}\right.$ exchangeable); $\mathrm{MS}: \mathrm{m} / z(\%) 353\left(\mathrm{M}^{+}\right.$, 2.9). Anal. Calcd. for $\mathrm{C}_{18} \mathrm{H}_{15} \mathrm{~N}_{3} \mathrm{O}_{3} \mathrm{~S}$ : C, 61.18; H, 4.28; N, 11.89; S, 9.07. Found: C, $61.08 ; \mathrm{H}, 4.06 ; \mathrm{N}, 11.62 ; \mathrm{S}, 9.25$. 
Synthesis of 2-cyano-3-(4-hydroxy-3-methoxyphenyl)-N-(p-tolylcarbamothioyl) acrylamide (9b)

Yield: 60\%; m.p.: $189-190{ }^{\circ} \mathrm{C}$; IR $\left(\mathrm{KBr}, \mathrm{cm}^{-1}\right): 3390-3287$ (2NH), 2220 $(\mathrm{CN}), 1680(\mathrm{C}=\mathrm{O}), 1370(\mathrm{C}=\mathrm{S}) ;{ }^{1} \mathrm{H}$ NMR (DMSO-d $): \delta 2.35\left(\mathrm{~s}, 3 \mathrm{H}, \mathrm{CH}_{3}\right), 3.91$ $\left(\mathrm{s}, 3 \mathrm{H}, \mathrm{OCH}_{3}\right), 6.93-7.74(\mathrm{~m}, 7 \mathrm{H}, \mathrm{Ar}-\mathrm{H}), 8.34(\mathrm{~s}, 1 \mathrm{H}, \underline{\mathrm{HC}}=\mathrm{C}-), 9.61(\mathrm{~s}, 1 \mathrm{H}, \mathrm{NH}$, $\mathrm{D}_{2} \mathrm{O}$ exchangeable), $10.54\left(\mathrm{~s}, 1 \mathrm{H}, \mathrm{NH}, \mathrm{D}_{2} \mathrm{O}\right.$ exchangeable), $12.33(\mathrm{~s}, 1 \mathrm{H}, \mathrm{OH}$, $\mathrm{D}_{2} \mathrm{O}$ exchangeable); MS: $m / z(\%) 367\left(\mathrm{M}^{+}, 14.8\right)$. Anal. Calcd. for $\mathrm{C}_{19} \mathrm{H}_{17} \mathrm{~N}_{3} \mathrm{O}_{3} \mathrm{~S}$ : C, 62.11; H, 4.66; N, 11.44; S, 8.73. Found: C, 62.45; H, 4.54; N, 11.39; S, 8.65.

Synthesis of tautomeric mixture $(8 b \rightleftharpoons 9 c)$

Yield: 83\%; m.p.: 190-191 ${ }^{\circ} \mathrm{C}$; IR (KBr, cm $\left.{ }^{-1}\right): 3387$ (NH), $2210(\mathrm{CN}), 1690$ $(\mathrm{C}=\mathrm{O}), 1370(\mathrm{C}=\mathrm{S}) ;{ }^{1} \mathrm{H}$ NMR $\left(\mathrm{DMSO}-d_{6}\right): \delta 3.79\left(\mathrm{~s}, 3 \mathrm{H}, \mathrm{OCH}_{3}\right), 3.88(\mathrm{~s}, 3 \mathrm{H}$, $\left.\mathrm{OCH}_{3}\right),\left[5.62,5.35,5.14\right.$ (3dd, pyrimidine $\mathrm{H}_{\mathrm{a}}$ and $\mathrm{H}_{\mathrm{b}}$ of $\mathbf{8 b}$ and $9.24(\mathrm{NH}), 8.21$ $(\underline{\mathrm{HC}}=\mathrm{C}-)$ 2s, of 9c, 2H], 6.98-7.59 (m, 7H, Ar-H), $10.51\left(\mathrm{~s}, 1 \mathrm{H}, \mathrm{NH}, \mathrm{D}_{2} \mathrm{O}\right.$ exchangeable), $11.91\left(\mathrm{~s}, 1 \mathrm{H}, \mathrm{OH}, \mathrm{D}_{2} \mathrm{O}\right.$ exchangeable); MS: $\mathrm{m} / z(\%) 383\left(\mathrm{M}^{+}\right.$, 20.6). Anal. Calcd. for $\mathrm{C}_{19} \mathrm{H}_{17} \mathrm{~N}_{3} \mathrm{O}_{4} \mathrm{~S}$ : C, 59.52; H, 4.47; N, 10.96; S, 8.36. Found: C, 59.34; H, 4.20; N, 11.12; S, 8.25.

Synthesis of 2 - (5 - ( 4-hydroxy - 3-methoxybenzylidene )- 6-imino -4-oxo-2thioxotetrahydropyrimidin-1(2H)-yl)acetic acid (11)

Glycine $(0.71 \mathrm{~g}, 0.01 \mathrm{~mol})$ was added to a solution of acryloyl isothiocyanate (2) $(0.01 \mathrm{~mol})$ prepared in situ in dry acetone. The reaction mixture was heated under reflux on a boiling water bath for $1.5 \mathrm{hr}$. On evaporation of the excess acetone, a solid product was precipitated, washed with cold water to get rid of unreacted glycine and crystallized from toluene.

Yield: 55\%; m.p.: $174-175{ }^{\circ} \mathrm{C}$; IR $\left(\mathrm{KBr}, \mathrm{cm}^{-1}\right): 3600-3200$ (br. OH), 1810, $1770(2 \mathrm{C}=\mathrm{O}), 1370(\mathrm{C}=\mathrm{S}) ;{ }^{1} \mathrm{H}$ NMR $\left(\mathrm{DMSO}-d_{6}\right): \delta 3.77\left(\mathrm{~s}, 3 \mathrm{H}, \mathrm{OCH}_{3}\right), 3.98(\mathrm{~s}$, $1 \mathrm{H},-\mathrm{C}=\mathrm{NH}, \mathrm{D}_{2} \mathrm{O}$ exchangeable $), 4.67\left(\mathrm{~s}, 2 \mathrm{H}, \mathrm{CH}_{2}\right), 6.98-7.31(\mathrm{~m}, 3 \mathrm{H}, \mathrm{Ar}-\mathrm{H})$, $7.94(\mathrm{~s}, 1 \mathrm{H}, \mathrm{HC}=\mathrm{C}-), 8.41\left(\mathrm{~s}, 1 \mathrm{H}, \mathrm{NH}, \mathrm{D}_{2} \mathrm{O}\right.$ exchangeable) $10.54(\mathrm{~s}, 1 \mathrm{H}, \mathrm{OH}$, $\mathrm{D}_{2} \mathrm{O}$ exchangeable), 11.33 (s, $1 \mathrm{H}, \mathrm{OH}, \mathrm{D}_{2} \mathrm{O}$ exchangeable); MS: $m / z$ (\%) 335 $\left(\mathrm{M}^{+}\right.$, 5.7). Anal. Calcd. for $\mathrm{C}_{14} \mathrm{H}_{13} \mathrm{~N}_{3} \mathrm{O}_{5} \mathrm{~S}$ : C, 50.14; H, 3.91; N, 12.53; S, 9.56. Found: C, 50.33; H, 3.72; N, 12.34; S, 9.31.

\section{References}

1. Ramesh, B. and Bhalgat, C.M., Novel dihydropyrimidines and its pyrazole derivatives: Synthesis and pharmacological screening. Eur. J. Med. Chem. 46, 1882-1891 (2011).

2. Ramesh, B., Bharathi, D.R., Basavaraj, H.S. and Jayadevaiah K.V., Synthesis and antimicrobial activity of tri-substituted 1,6-dihydropyrimidines. Asian J. Chem. 20, 2591-2596 (2008).

3. Mohamed, M.S., Awad, S.M. and Ahmed N.M., Synthesis and antimicrobial evaluation of some 6-aryl-5-cyano-2-thiouracil derivatives. Acta Pharm. 61, 171-185 (2011).

4. Markley, L.D., Arndt, K.E., Balko, T.W., Bargar T.M., Green F.R. and Jackson J.L. et al., In $2^{\text {nd }}$ ACS National Meeting, Chicago, IL, USA (2001).

Egypt. J. Chem. 58, No. 6 (2015) 
5. Sanemitsu, Y. and Kawamura, S., Studies on the synthetic development for the discovery of novel heterocyclic agrochemicals. J. Pesticide Sci. 33, 175-177(2008).

6. Hargreaves, S.L., Pilkington, B.L., Russell, S.E. and Worthington, P.A., The synthesis of substituted pyridylpyrimidine fungicides using palladium-catalysed crosscoupling reactions. Tetrahedron Lett. 41 (10), 1653-1656 (2000).

7. Mugnaini, C., Petricci, E., Botta, M., Corelli, F., Mastromarino, P. and Giorgi, G., Synthesis and biological evaluation of 4-alkylamino-6-(2-hydroxyethyl)-2methylthiopyrimidines as new rubella virus inhibitors. Eur. J. Med. Chem. 42 (2), 256-262 (2007).

8. Edwards, P., The use of parallel chemistry for the generation of micromolar hits against biological targets. Drug Discov. Today, 13, 275-276 (2008).

9. Amir, M. and Shikha K., Synthesis and anti-inflammatory, analgesic, ulcerogenic and lipid peroxidation activities of some new 2-[(2,6-dichloroanilino) phenyl]acetic acid derivatives. Eur. J. Med. Chem. 39, 535-545 (2004).

10. Palaska, E., Sahin, G., Kelicen, P., Durlu, N.T. and Altinok, G., Synthesis and antiinflammatory activity of 1-acylthiosemicarbazides, 1,3,4-oxadiazoles, 1,3,4thiadiazoles and 1,2,4-triazole-3-thiones. Farmaco, 57 (2), 101-107 (2002).

11. Sharma, R., Sainy, J. and Chaturvedi, S.C., 2-Amino-5-sulfanyl-1,3,4-thiadiazoles: A new series of selective cyclooxygenase-2 inhibitors. Acta Pharm. 58, 317-326 (2008).

12. Dogan, H.N., Duran, A., Rollas, S., Sener, G., Uysal, M.K. and Gülen, D., Synthesis of new 2,5-disubstituted-1,3,4-thiadiazoles and preliminary evaluation of anticonvulsant and antimicrobial activities. Bioorg. Med.Chem., 10, 2893-2898 (2002).

13. Alafeefy, A.M., Synthesis and antimicrobial activity of some new quinazolin-4(3H)one derivatives. Pharm. Biol. 46, 751-756 (2008).

14. Alagarsamy, V., Murugesan, S. and Sheorey, R.V., Synthesis and pharmacological investigation of novel 3-(benzyl)-2-substituted amino-3H-quinazolin-4-ones as analgesic and anti-inflammatory agents. Med. Chem. Res. 17 (9), 564-577 (2008).

15. Raffa, D., Edler, M. C., Daidone, G., Maggio, B., Merickech, M., Plescia, S., Schillaci, D., Bai, R. and Hamel, E., Synthesis, cytotoxicity, and inhibitory effects on tubulin polymerization of a new 3-heterocyclo substituted 2-styrylquinazolinones. Eur. J. Med. Chem. 39, 299-304 (2004).

16. Maarouf, A.R., El-Bendary, E.R. and Goda, F.E., Synthesis and evaluation of some novel quinazolinone derivatives as diuretic agents. Arch Pharm. 337 (10), 527-532 (2004).

17. Ying, A.- G. Liu, L., Wu, G.- F., Chen, G., Chen, X.- Z. and Ye, W.- D., AzaMichael addition of aliphatic or aromatic amines to $\alpha, \beta$-unsaturated compounds catalyzed by a DBU-derived ionic liquid under solvent-free conditions. Tetrahedron Lett. 50 (14), 1653-1657 (2009) 
18. Unkovskii, B.V., Ignatova, L.A. and Zaitseva, M.G., Synthesis and ring-chain tautomerism of substituted 4-hydroxy-hexahydropyrimidine-2-thiones. Chem. Heterocycl .Compd. 5 (5), 662-666 (1969).

19. Yu. Ershov, A., Nasledov, D.G., Nasonova, K.V., Sezyavina K.V., Susarova T.V., Lagoda, L.V. and Shamanin, V.V., Ring-chain tautomerism of 2-aryl-6-oxohexahydropyrimidine -4carboxylic acid sodium salts. Chem. Heterocycl .Compd. 49 (4), 598-603 (2013).

20. Moskovkin, A.S., Guseva, N.N., Ignatova, L.A., Miroshnichenko, I.V. and Unkovskii , B. V., Mass-spectrometric study of ring-chain tautomerism in a series of substituted 4hydroxyhexahydropyrimidine-2-thiones. Chem. Heterocycl .Compd. 19 (9), 10221026 (1983).

21. Nitsch, J.P. and Colette Nitsch, Studies on the growth of coleoptile and first internode sections. A new, sensitive, straight-growth test for auxins. Plant Physiol. 31 (2), 94-111 (1956).

22. Ansari, F.L., Nazir, S., Noureen, H. and Miraza, B., Combinatorial synthesis and antibacterial evaluation of an indexed chalcone library. Chem. Biodivers. 2, 16561664 (2005).

23. Vincent, J.G. and Vincent, H.W., Filter paper disc modification of the Oxford cup penicillin determination. Proc. Soc. Exp. Biol. Med. 55, 162-164 (1944).

24. Shanthan Roo, P. and Venkataratham, R.V., Zinc chloride as a new catalyst for knoevenagel condensation. Tetrahedron Lett. 32 (41), 5821-5822 (1991).

(Received 13/9/2015;

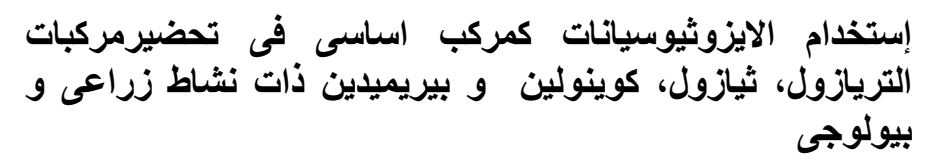

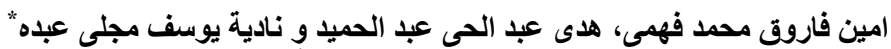

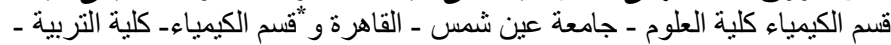

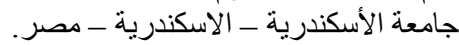

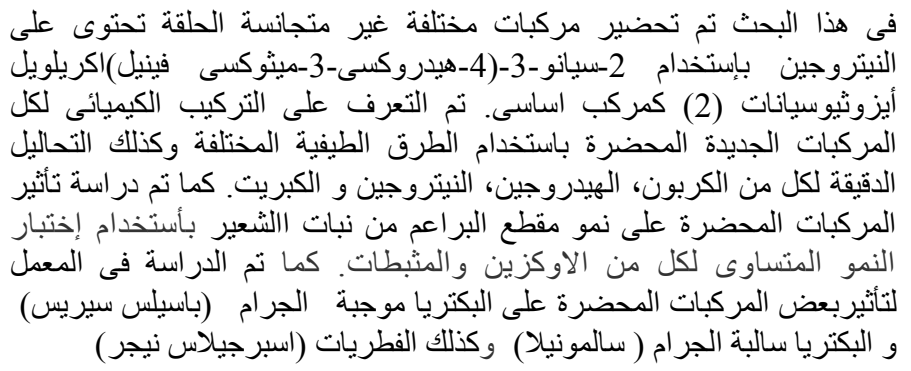

